\title{
MONITORING APLIKASI MENGGUNAKAN DASHBOARD UNTUK SISTEM INFORMASI AKUNTANSI PEMBELIAN DAN PENJUALAN (STUDI KASUS : UD APUNG)
}

\author{
Sufia Maulida ${ }^{1)}$, Fikri Hamidy ${ }^{2}$, Agung Deni Wahyudi ${ }^{3)}$ \\ 1) Informatika, Universitas Teknokrat Indonesia \\ 2) Sistem Informasi Akuntansi, Universitas Teknokrat Indonesia \\ ${ }^{3}$ Sistem Informasi, Universitas Teknokrat Indonesia \\ Jl. H.ZA Pagaralam, No 9-11, Labuhanratu,Bandarlampung \\ Email : sufiamaulida96@gmail.com ${ }^{1)}$,fikrihamidy@teknokrat.ac.id ${ }^{2}$, agungwahyudi57@gmail.com ${ }^{3)}$
}

\begin{abstract}
Abstrak
UD Apung sebuah usaha dagang yang bergerak pada bidang penjualan barang yang mendistribusikan barang dagangannya kepada pelanggan. Proses penjualan barang yang dilakukan masih secara konvensional yaitu melakukan pencatatan pada nota penjualan barang yang akan dikirim kepada pelanggan. Permasalahan yang ada pada proses penjualan yaitu pembuatan nota penjualan dan faktur pengiriman barang masih dilakukan secara manual yaitu dengan menulis pada nota dan faktur pengiriman barang untuk diberikan kepada pelanggan sehingga memperlambat kinerja staff dalam pengolahan transaksi penjualan. Sistem informasi akuntansi (SIA) adalah sebuah sistem yang mengumpulkan, menyimpan dan mengolah data keuangan dan akuntansi yang digunakan oleh pengambil keputusan. Sistem dashboard interaktif ini dapat mempermudah bagian staff dalam menyajikan laporan penjualan secara real time dan memudahkan pimpinan dalam melihat perkembangan penjualan dan melakukan pengolahan data penjualan. Digital dahsboard yang baik dapat meningkatkan efektifitas eksekutif perusahaan dalam proses pengambilan keputusan. Tujuan monitoring aplikasi dengan menggunakan dashboard pada sistem informasi akuntansi pembelian dan penjualan barang pada UD Apung yaitu: Memastikan proses input transaksi penjualan dan pembelian barang dilakukan sesuai prosedur yang berlaku oleh bagian staff, sehingga proses input transaksi penjualan dan pembelian barang berjalan sesuai jalur yang disediakan). Menyediakan probabilitas tinggi akan keakuratan data bagi pelaku monitoring yaitu dengan menampilkan data transaksi penjualan dan pembelian dalam bentuk grafik, sehingga pimpinan dapat melihat data transaksi penjualan dan pembelian barang secara cepat dan akurat.
\end{abstract}

Kata kunci: Monitoring, Dashboard, Sistem Informasi Akuntansi, Penjualan, Pembelian

\section{Pendahuluan}

Sistem informasi akuntansi (SIA) adalah sebuah sistem yang mengumpulkan, menyimpan dan mengolah data keuangan dan akuntansi yang digunakan oleh pengambil keputusan. Informasi akuntansi merupakan sistem yang umumnya berbasis komputer dan metode untuk melacak kegiatan akuntansi dalam hubungannya dengan sumber daya teknologi informasi. Hasil laporan-laporan keuangan dapat digunakan secara internal oleh manajemen atau secara eksternal dengan pihak lain yang berkepentingan seperti investor, kreditur dan otoritas pajak. Sistem informasi akuntansi dirancang untuk mendukung semua fungsi akuntansi dan berbagai kegiatan termasuk audit, akuntansi keuangan dan pelaporannya, manajerial atau manajemen akuntansi dan pajak. Penerapan sistem informasi akuntansi secara komputerisasi lebih menguntungkan perusahaan dibandingkan dengan biaya yang harus dikeluarkan perusahaan dalam mejalankan sistem informasi akuntansi secara manual (Widyatmini dan Faradila, 2014).

UD Apung sebuah usaha dagang yang bergerak pada bidang penjualan barang untuk alat bangunan yang mendistribusikan barang dagangannya kepada pelanggan. Proses penjualan barang yang dilakukan masih secara konvensional yaitu melakukan pencatatan pada nota penjualan barang yang akan dikirim kepada pelanggan. Permasalahan yang ada pada proses penjualan yaitu pembuatan nota penjualan dan faktur pengiriman barang masih dilakukan secara manual yaitu dengan menulis pada nota dan faktur pengiriman barang untuk diberikan kepada pelanggan sehingga memperlambat kinerja staff dalam pengolahan transaksi penjualan. Dalam proses pembelian barang dari supplier UD Apung juga memiliki permasalahan yaitu pencatatan barang ketika melakukan pembelian barang masih dicatat pada buku stok barang dan dijumlahkan dengan kalkulator untuk mengetahui jumlah stok barang secara keseluruhan. Sehingga perlu membuat sebuah sistem informasi akuntansi penjualan dan pembelian barang pada UD Apung untuk mempermudah staff dalam pengolahan data transaksi penjualan dan pembelian barang.

Monitoring penjualan dan pembelian pada UD Apung hanya melakukan pencocokan data antara stok barang, pembelian barang, dan penjualan barang dari transaksi 
yang telah dilakukan. Perekapan data penjualan, pembelian, stok barang yang terjadi didapat dari nota penjualan barang dan nota pembelian barang, untuk dibuatkan laporan penjualan barang, laporan pembelian barang, dan laporan stok barang dengan menggunakan Ms. Excel sehingga membutuhkan waktu yang lama dalam pembuatan laporan untuk diberikan kepada pimpinan. Sistem dashboard interaktif ini dapat mempermudah bagian staff dalam menyajikan laporan penjualan secara real time dan memudahkan pimpinan dalam melihat perkembangan penjualan dan melakukan pengolahan data penjualan (Sulistiani dan Sulistiawati, 2018). Digital dahsboard yang baik dapat meningkatkan efektifitas eksekutif perusahaan dalam proses pengambilan keputusan (Suhaidir dan Sensuse, 2010).

\subsection{Rumusan Masalah}

Berdasarkan uraian dari latar belakang yang telah dijelaskan di atas, maka permasalahan yang dapat dirumuskan yaitu

1. Bagaimana melakukan monitoring dengan menggunakan dashboard pada sistem informasi akuntansi pembelian dan penjualan barang pada UD Apung?

2. Bagaimana mengetahui hasil pengujian dari monitoring aplikasi menggunakan dashboard pada sistem informasi akuntansi pembelian dan penjualan barang pada UD Apung?

\subsection{Tujuan}

Tujuan yang di peroleh dari penelitian ini adalah membuat monitoring aplikasi menggunakan dashboard untuk sistem informasi akuntansi pembelian dan penjualan barang dagang adalah:

1. Menghasilkan aplikasi monitoring dengan menggunakan dashboard pada sistem informasi akuntansi pembelian dan penjualan barang untuk mengatasi permasalahan pada proses penjualan, pembelian dan persediaan barang pada UD Apung.

2. Mengetahui hasil pengujian dari monitoring aplikasi menggunakan dashboard pada sistem informasi akuntansi pembelian dan penjualan barang pada UD Apung dengan menggunakan pengujian black box testing dan Model DeLone and McLean.

\subsection{Landasan Teori}

Monitoring merupakan suatu kegiatan mengamati secara seksama suatu keadaan atau kondisi, termasuk juga perilaku atau kegiatan tertentu, dengan tujuan agar semua data masukan atau informasi yang diperoleh dari hasil pengamatan tersebut dapat menjadi landasan dalam mengambil keputusan tindakan selanjutnya yang diperlukan.

Sistem monitoring akan memberikan dampak yang baik bila dirancang dan dilakukan secara efektif. Berikut kriteria sistem monitoring yang efektif :

1. Sederhana dan mudah dimengerti (user friendly). Monitoring harus dirancang dengan sederhana namun tepat sasaran. Konsep yang digunakan adalah singkat, jelas, dan padat. Singkat berarti sederhana, jelas berarti mudah dimengerti, dan padat berarti bermakna (berbobot).

2. Fokus pada beberapa indikator utama. Indikator diartikan sebagai titik kritis dari suatu scope tertentu. Banyaknya indikator membuat pelaku dan obyek monitoring tidak fokus. Hal ini berdampak pada pelaksanaan sistem tidak terarah. Maka itu, fokus diarahkan pada indikator utama yang benar-benar mewakili bagian yang dipantau.

3. Perencanaan matang terhadap aspek-aspek teknis. Tujuan perancangan sistem adalah aplikasi teknis yang terarah dan terstruktur. Maka itu, perencanaan aspek teknis terkait harus dipersiapkan secara matang. Aspek teknis dapat menggunakan pedoman 5W1H, meliputi apa, mengapa, siapa, kapan, di mana dan bagaimana pelaksanaan sistem monitoring.

4. Prosedur pengumpulan dan penggalian data. Selain itu, data yang didapatkan dalam pelaksanaan monitoring pada on going process harus memiliki prosedur tepat dan sesuai. Hal ini ditujukan untuk kemudahan pelaksanaan proses masuk dan keluarnya data. Prosedur yang tepat akan menghindari proses input dan output data yang salah (tidak akurat).

Dashboard adalah sebuah antar muka komputer yang banyak menampilkan bagan, grafik, laporan, indikator visual, dan mekanisme alert, yang akan dikonsolidasi ke dalam platform informasi yang dinamis dan relevan. Dashboard berperan sebagai live console untuk mengelola inisiatif bisnis (Malik, 2005).

Information dashboard sebagai tampilan visual dari informasi penting yang diperlukan untuk mencapai suatu tujuan dengan mengkonsolidasikan dan mengatur dalam satu layar (single screen), sehingga kinerja organisasi dapat dimonitor secara sekilas (Few, 2006).

fitur yang paling membedakan dari suatu dashboard adalah adanya tiga layer informasi:

\section{Monitoring.}

Data grafis yang sudah disarikan untuk memonitor berbagai macam metrik performa utama atau kunci.

\section{Analysis.}

Data dimensional yang sudah ringkas untuk menganalisa akar penyebab berbagai macam problem.

\section{Management.}

Data operasional detail untuk mengetahui tindakantindakan apa yang seharusnya diambil untuk memecahkan masalah.

Dalam pengembangan sistem akuntansi untuk suatu perusahaan, terdapat beberapa fungsi dasar sistem informasi akuntansi, fungsi dasar sistem informasi akuntansi (Romney and Steinbart, 2014) yaitu:

1. Mengumpulkan dan menyimpan data mengenai aktivitas, sumber daya, dan personel organisasi. 
2. Mengubah data menjadi informasi sehingga manajemen dapat merencanakan, mengeksekusi, mengendalikan dan mengevaluasi aktivitas, sumber daya, dan personel.

3. Memberikan pengendalian yang memadai untuk.mengamankan aset dan data organisasi

\section{Pembahasan}

Metode penelitian yang digunakan dalam adalah menggunakan kerangka penelitian untuk mencari solusi dari permasalahaan yang ada yaitu

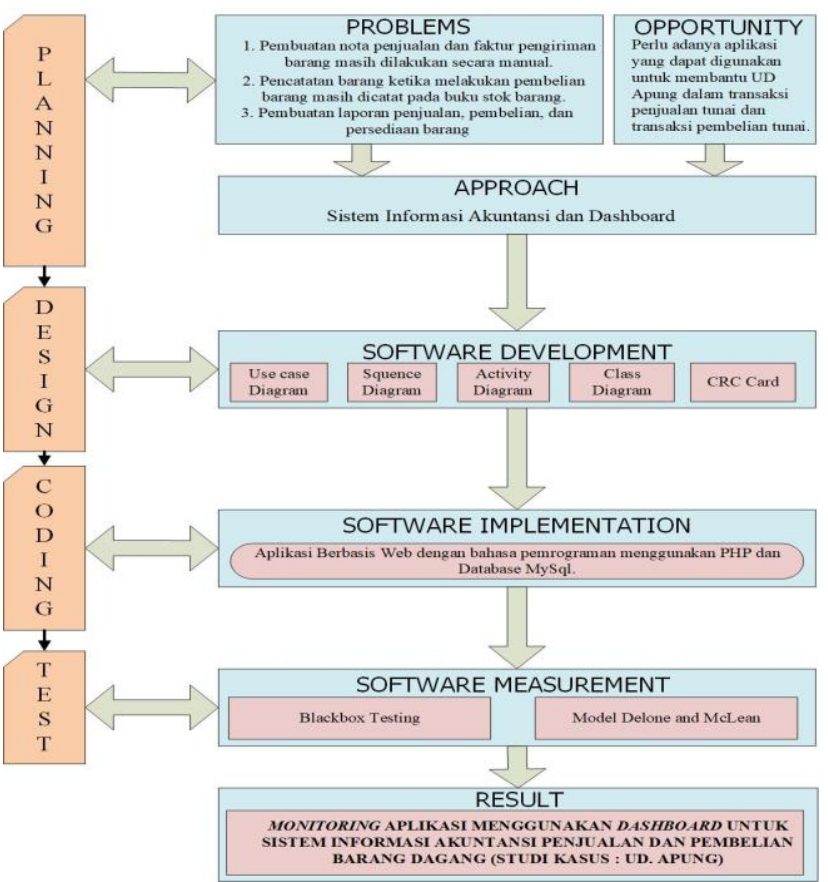

Gambar 1. Kerangka Penelitian

Penjelasan kerangka penelitian adalah

1. Tahapan Planning

Melakukan wawancara pada UD Apung untuk mendapatkan informasi tentang permasalahan yang terjadi dalam sistem penjualan dan pembelian barang. Selanjutnya dari permasalahan tersebut menentukan opportunity yaitu perlu adanya aplikasi yang dapat digunakan untuk membantu UD Apung dalam transaksi penjualan tunai dan transaksi pembelian tunai. Tahapan selanjutnya menggunakan pendekatan sistem informasi akuntansi untuk mengatasi permasalahan pada UD Apung.

\section{Tahapan Design}

Tahapan design yaitu membuat sebuah rancangan sistem informasi akuntansi dengan menggunakan permodelan berorientasi objek yaitu merancang Usecase Diagram, CRC Card, Class Diagram, Activity Diagram, dan Sequence Diagram.

\section{Tahapan Coding}

Tahapan coding yaitu membuat aplikasi berbasis web dengan bahasa pemrograman menggunakan PHP dan Database MySql.

4. Tahapan Test

Tahapan test yaitu membuat pengujian terhadap aplikasi yang sudah dibuat dengan menggunakan blackbox testing untuk menguji fungsionalitas sistem. Test case ini bertujuan untuk menunjukan fungsi perangkat lunak tentang cara beroperasinya. Serta model DeLone and McLean untuk menguji kesuksesan sistem informasi (DeLone and McLean, 2003))

\subsection{Analisis Kebutuhan Fungsional Sistem}

Analisis kebutuhan fungsional yaitu analisis kebutuhan yang dibutuhkan oleh sistem yang akan dibuat atau dikembangkan. Analisis kebutuhan fungsional dalam monitoring aplikasi menggunakan dashboard untuk sistem informasi akuntansi penjualan dan pembelian barang dagang (studi kasus : UD Apung) adalah :

1. Sistem dapat melakukan login aplikasi.

2. Sistem dapat menampilkan dashboard grafik.

3. Sistem dapat mengelola data barang.

4. Sistem dapat mengelola data pelanggan.

5. Sistem dapat mengelola data supplier.

6. Sistem dapat mengelola data sales.

7. Sistem dapat mengelola data penjualan tunai.

8. Sistem dapat mengelola data pembelian tunai.

9. Sistem dapat menampilkan dan mencetak laporan penjualan tunai.

10. Sistem dapat menampilkan dan mencetak laporan pembelian tunai.

11. Sistem dapat menampilkan dan mencetak laporan persediaan.

12. Sistem dapat menampilkan dan mencetak ikhtisar jurnal umum.

13. Sistem dapat menampilkan dan mencetak ikhtisar jurnal pengeluaran kas.

14. Sistem dapat menampilkan dan mencetak ikhtisar jurnal penerimaan kas.

15. Sistem dapat menampilkan dan mencetak ikhtisar buku besar.

16. Sistem dapat melakukan logout aplikasi.

Analisis fungsional sistem yang telah dibuat akan mempermudah bagian staff dalam melakukan proses transaksi penjualan dan pembelian barang sehingga mempercepat proses pencocokan dalam pencatatan data transaksi penjualan dan pembelian. Serta mempermudah pimpinan dalam melakukan monitoring penjualan dan pembelian barang dan menghasikan informasi secara akurat untuk pengambilan keputusan bagi perusahaan.

\subsection{Perancangan Sistem}


Use case diagram monitoring aplikasi menggunakan dashboard untuk sistem informasi akuntansi penjualan dan pembelian barang dagang adalah sebagai berikut

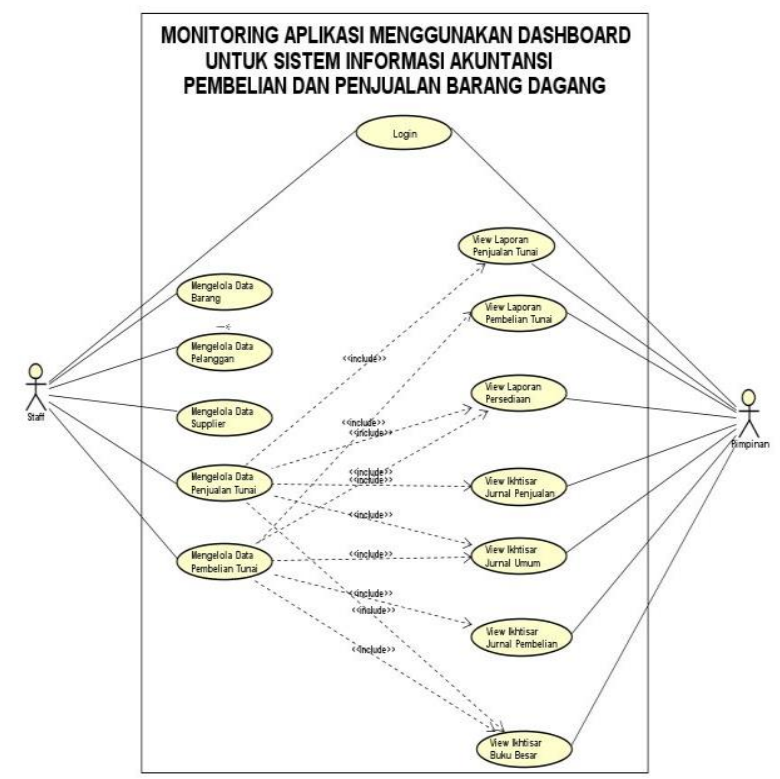

Gambar 2. Use Case Diagram

Use case diagram diatas terdapat 2 aktor yaitu bagian staff dan pimpinan. Aktor bagian staff dapat melakukan use case login, use case mengelola data barang, use case mengelola data pelanggan, use case mengelola data supplier, use case mengelola data sales, use case mengelola data pembelian tunai, use case mengelola penjualan tunai. Aktor pimpinan dapat melakukan use case login, use case view laporan penjualan tunai, use case view laporan pembelian tunai, use case view laporan persediaan, use case view ikhtisar jurnal umum, use case view ikhtisar jurnal pengeluaran kas, use case view ikhtisar jurnal penerimaan kas, use case view ikhtisar buku besar.

\subsection{Implementasi Sistem}

Implementasi sistem adalah suatu proses untuk menempatkan sistem informasi baru ke dalam sistem yang sudah ada (sistem lama). Hasil prototype ini akan menjelaskan tentang hasil penelitian dan pembuatan prototype, sehingga mengetahui hasil apakah prototype yang telah dibuat dapat mencapai tujuan yang diinginkan. Pembahasan tentang Hasil monitoring aplikasi menggunakan dashboard untuk sistem informasi akuntansi pembelian dan penjualan adalah sebagai berikut

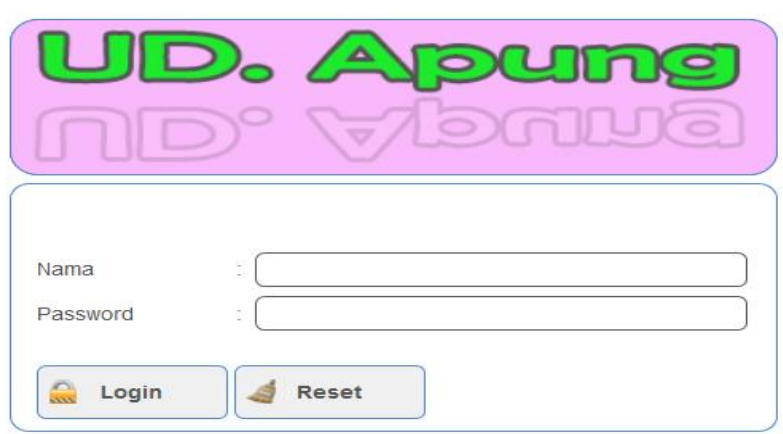

Gambar 3. Implementasi Halaman Login

Implementasi halaman login adalah tampilan ketika pengguna akan mengakses aplikasi yang dibuat. Sebelum menggunakan sistem pengguna harus terlebih dahulu melakukan login.

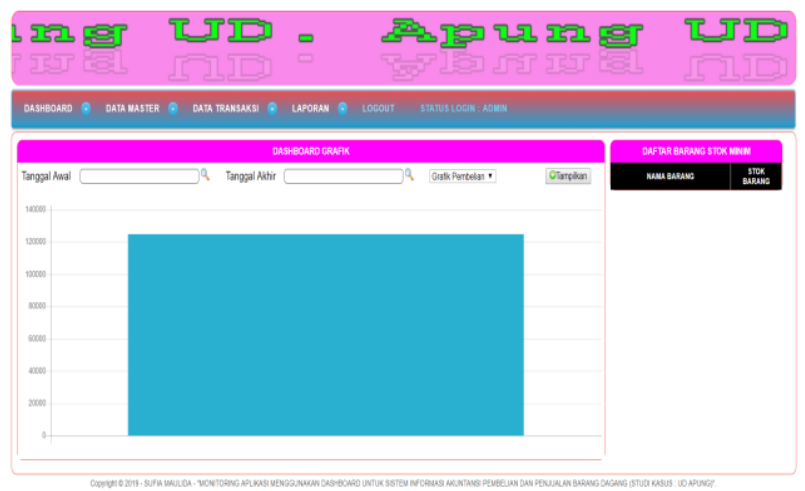

Gambar 4. Implementasi Halaman Dashboard

Implementasi halaman dashboard adalah tampilan ketika pengguna berhasil melakukan login. Halaman dashboard untuk melihat grafik penjualan dan grafik pembelian barang yang terjadi pada UD Apung. Dashboard berperan sebagai live console untuk mengelola inisiatif bisnis.

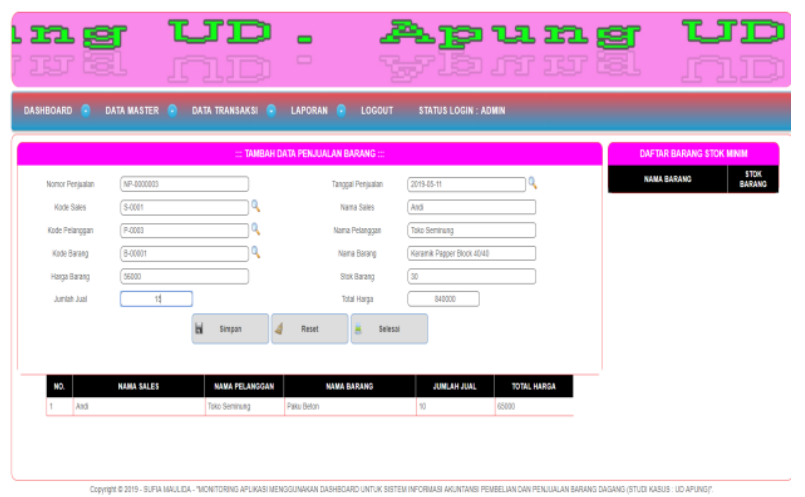

Gambar 5. Implementasi Halaman Penjualan

Halaman tambah data penjualan tunai untuk melakukan input data penjualan tunai baru yaitu input nomor nota penjualan yang akan terisi secara otomatis berdasarkan jumlah transaksi yang ada, input tanggal penjualan, input kode pelanggan, dan input nama pelanggan yang akan dilakukan pencarian data berdasarkan data pelanggan yang telah tersimpan dalam database. Input kode barang, input nama barang, input 
harga jual, input stok barang yang akan dilakukan pencarian data berdasarkan data barang yang telah tersimpan dalam database.

\subsection{Pengujian Sistem}

Hasil pengujian fungsionalitas sistem terhadap halaman yang terdapat pada monitoring aplikasi dengan menggunakan dashboard pada sistem informasi akuntansi pembelian dan penjualan barang telah dilakukan pada pengguna sistem. Responden untuk pengujian sistem ini berjumlah 3 responden yaitu responden yang mempunyai keahlian dalam bidang software engineering mempunyai jabatan sebagai dosen pada Universitas Teknokrat Indonesia. Berdasarkan hasil pengujian tersebut, maka diperoleh kesimpulan bahwa hasil pengujian tersebut yang telah sesuai dengan hasil yang diharapkan dalam kuisioner pengujian black box testing.

Tabel 1. Hasil Pengujian Blackbox Testing

\begin{tabular}{|c|c|c|}
\hline \multirow{2}{*}{ Kriteria Pengujian } & \multicolumn{2}{|c|}{$\begin{array}{l}\text { Jumlah } \\
\text { Jawaban }\end{array}$} \\
\hline & Sesuai & $\begin{array}{l}\text { Tidak } \\
\text { Sesuai }\end{array}$ \\
\hline Halaman Login & 12 & 0 \\
\hline Halaman Data Barang & 12 & 0 \\
\hline Halaman Data Supplier & 12 & 0 \\
\hline Halaman Data Sales & 12 & 0 \\
\hline Halaman Data Pelanggan & 12 & 0 \\
\hline Halaman Data Penjualan & 9 & 0 \\
\hline Halaman Data Pembelian & 9 & 0 \\
\hline Halaman Laporan Penjualan & 6 & 0 \\
\hline Halaman Laporan Pembelian & 6 & 0 \\
\hline Halaman Laporan Persediaan & 6 & 0 \\
\hline Halaman Laporan Jurnal Umum & 6 & 0 \\
\hline $\begin{array}{l}\text { Halaman Laporan Jurnal } \\
\text { Penerimaan Kas }\end{array}$ & 6 & 0 \\
\hline $\begin{array}{ll}\text { Halaman Laporan } & \text { Jurnal } \\
\text { Pengeluaran Kas } & \\
\end{array}$ & 6 & 0 \\
\hline Halaman Laporan Buku Besar & 6 & 0 \\
\hline Halaman Dashboard Grafik & 6 & 0 \\
\hline Total Jawaban & 126 & $\mathbf{0}$ \\
\hline
\end{tabular}

Berdasarkan hasil rekapitulasi 15 kriteria pengujian yang telah dilakukan didapatkan hasil jumlah jawaban dari responden yaitu mempunyai nilai $100 \%$ sesuai dengan pengujian fungsionalitas sistem menggunakan blackbox testing.

Pengujian kualitas informasi dari prototype dengan model DeLone and McLeon akan memaparkan hasil kualitas informasi berdasarkan masing-masing kriteria yaitu Kualitas Informasi (KI), Kualitas Sistem (KS), Kualitas Layanan (KL), Penggunaan (P), dan Kepuasan Pelanggan (KP). Selain itu juga pengujian ini akan dipaparkan hasil keseluruhan kualitas prototype yang dibuat, berdasarkan tanggapan 6 responden dari UD Apung yang telah mengisi kuisioner.

Berdasarkan hasil pengujian diperoleh dari kuisioner, hasil rekapitulasi pengujian kualitas informasi berdasarkan 5 kriteria kualitas kesuksesan sistem informasi dari prototype dengan model DeLone dan McLean.

Tabel 2. Hasil Pengujian Model DeLone and McLean

\begin{tabular}{|l|l|c|c|}
\hline No & \multicolumn{1}{|c|}{ Aspek / Kriteria } & $\begin{array}{c}\text { Skor } \\
\text { Aktual }\end{array}$ & $\begin{array}{c}\text { Skor } \\
\text { Ideal }\end{array}$ \\
\hline 1 & $\begin{array}{l}\text { Kualitas Informasi } \\
\text { (Information Quality) }\end{array}$ & 121 & 150 \\
\hline 2 & $\begin{array}{l}\text { Kualitas Sistem (System } \\
\text { Quality) }\end{array}$ & 122 & 150 \\
\hline 3 & $\begin{array}{l}\text { Kualitas Layanan (Service } \\
\text { Quality) }\end{array}$ & 74 & 90 \\
\hline 4 & Penggunaan (Use) & 48 & 60 \\
\hline 5 & $\begin{array}{l}\text { Kepuasan Pengguna (Use } \\
\text { Satisfaction) }\end{array}$ & 50 & 60 \\
\hline
\end{tabular}

Berdasarkan hasil pengolahan data tanggapan responden sebanyak 6 responden berdasarkan 5 kriteria Model DeLone dan McLeon maka didapatkan hasil dalam bentuk grafik perbandingan 5 kriteria Model DeLone dan McLeon dapat dilihat pada gambar berikut ini

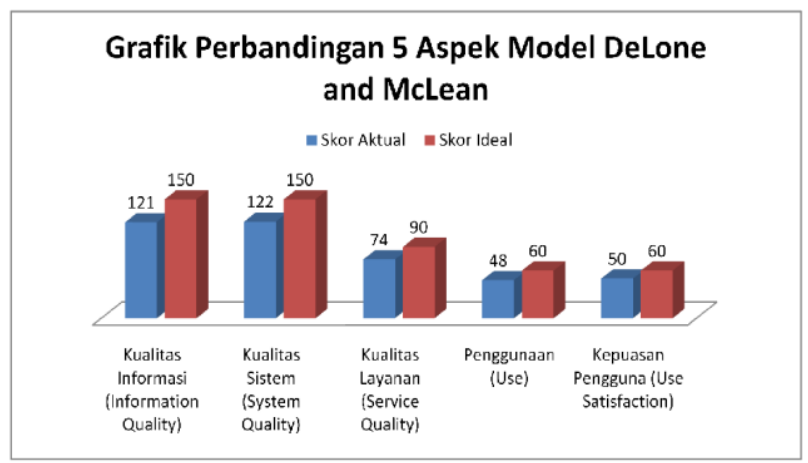

\section{Gambar 6. Grafik Pengujian Model DeLone and McLean}

Grafik perbandingan 5 kriteria Model DeLone dan McLeon didapat yaitu Kualitas Informasi (Information Quality) mempunyai nilai skor aktual yaitu 121 dan skor ideal yaitu 150, Kualitas Sistem (System Quality) mempunyai nilai skor aktual yaitu 122 dan skor ideal yaitu 150, Kualitas Layanan (Service Quality) mempunyai nilai skor aktual yaitu 74 dan skor ideal yaitu 90, Penggunaan (Use) mempunyai nilai skor aktual yaitu 48 dan skor ideal yaitu 60, Kepuasan Pengguna (Use Satisfaction) mempunyai nilai skor aktual yaitu 50 dan skor ideal yaitu 60 .

\subsection{Pembahasan}

Monitoring aplikasi dengan menggunakan dashboard pada sistem informasi akuntansi pembelian dan penjualan barang pada UD Apung dilakukan dengan melihat transaksi penjualan dan pembelian barang yang telah dilakukan melalui aplikasi yang dibuat sehingga pimpinan mudah dalam melakukan monitoring data penjualan dan pembelian yang terjadi dengan membuka aplikasi dan memilih menu dashboard. Data penjualan dan pembelian yang terjadi ditampilkan dalam bentuk grafik sehingga pimpinan dapat mengetahui secara cepat 
total transaksi pembelian dan penjualan yang terjadi pada perusahaan.

Tujuan monitoring aplikasi dengan menggunakan dashboard pada sistem informasi akuntansi pembelian dan penjualan barang pada UD Apung yaitu:

1. Memastikan proses input transaksi penjualan dan pembelian barang dilakukan sesuai prosedur yang berlaku oleh bagian staff, sehingga proses input transaksi penjualan dan pembelian barang berjalan sesuai jalur yang disediakan (on the track).

2. Menyediakan probabilitas tinggi akan keakuratan data bagi pelaku monitoring yaitu dengan menampilkan data transaksi penjualan dan pembelian dalam bentuk grafik, sehingga pimpinan dapat melihat data transksi penjualan dan pembelian barang secara cepat dan akurat.

3. Mengidentifikasi hasil yang tidak diinginkan pada suatu proses dengan cepat (tanpa menunggu proses selesai) yaitu dalam proses input data penjualan dan pembelian tidak memerlukan pencatatan secara manual seperti yang terjadi pada prosedur yang telah berjalan, sehingga dapat mengurangi kesalahan dalam melakuka input data penjualan dan pembelian yang akan menyebabkan kerugian perusahaan.

4. Menumbuh kembangkan motivasi dan kebiasaan positif pekerja yaitu mempermudah bagian staff dalam melakukan proses input data transaksi penjualan dan pembelian sehingga membantu mengurangi kesalahan input dan perhitungan penjualan dan pembelian yang terjadi oleh bagian staff.

Hasil pengolahan data rekapitulasi pengujian kualitas informasi berdasarkan 5 kriteria kualitas kesuksesan sistem informasi dari prototype dengan model DeLone dan McLean

Tabel 3. Rekapitulasi Pengujian DeLone and McLean

\begin{tabular}{|c|c|c|c|c|}
\hline $\begin{array}{l}\mathbf{N} \\
\mathbf{0}\end{array}$ & Aspek / Kriteria & $\begin{array}{c}\text { Skor } \\
\text { Aktual }\end{array}$ & $\begin{array}{l}\text { Skor } \\
\text { Ideal }\end{array}$ & $\begin{array}{c}\% \\
\text { Skor } \\
\text { Total } \\
\end{array}$ \\
\hline 1 & $\begin{array}{l}\text { Kualitas Informasi } \\
\text { (Information } \\
\text { Quality) }\end{array}$ & 121 & 150 & 80,67 \\
\hline 2 & $\begin{array}{l}\text { Kualitas Sistem } \\
\text { (System Quality) }\end{array}$ & 122 & 150 & 81,33 \\
\hline 3 & $\begin{array}{l}\text { Kualitas Layanan } \\
\text { (Service Quality) }\end{array}$ & 74 & 90 & 82,22 \\
\hline 4 & Penggunaan (Use) & 48 & 60 & 80 \\
\hline 5 & $\begin{array}{l}\text { Kepuasan } \\
\text { Pengguna } \\
\text { Satisfaction) }\end{array}$ & 50 & 60 & 83,33 \\
\hline & Total & 415 & 510 & 81,37 \\
\hline
\end{tabular}

Dari keseluruhan kriteria Model DeLone dan McLeon untuk kesuksesan sistem informasi hasilnya Baik sebesar $81,37 \%$.

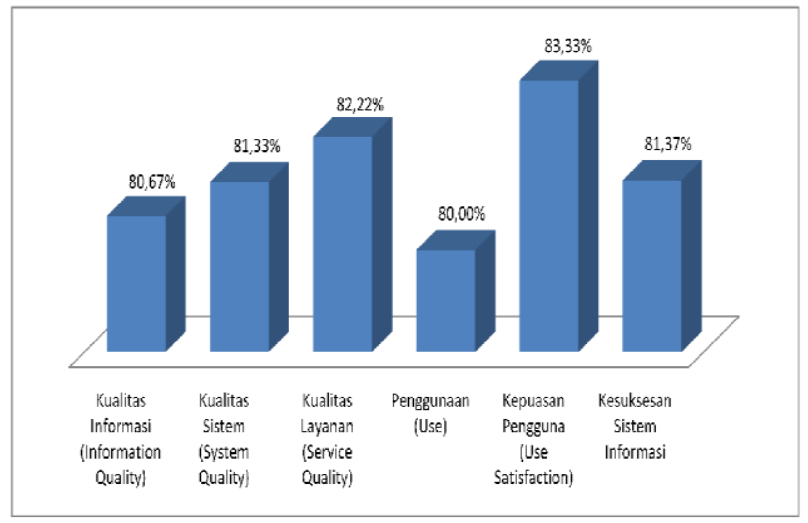

Gambar 7. Grafik Hasil Model DeLone and McLean

Grafik perbandingan 5 kriteria Model DeLone dan McLeon didapat yaitu Kualitas Informasi (Information Quality) sebesar 80,66\% dengan hasil kriteria yaitu baik, Kualitas Sistem (System Quality) sebesar $81,33 \%$ dengan hasil kriteria yaitu baik, Kualitas Layanan (Service Quality) sebesar 82,22\% dengan hasil kriteria yaitu baik, Penggunaan (Use) sebesar $80 \%$ dengan hasil kriteria yaitu baik, Kepuasan Pengguna (Use Satisfaction) sebesar 83,33\% dengan hasil kriteria yaitu baik. Dari keseluruhan kriteria Model DeLone dan McLeon untuk kesuksesan sistem informasi sebesar $81,37 \%$ dengan hasil kriteria yaitu baik.

\subsection{Evaluasi Sistem}

Sistem monitoring aplikasi dengan menggunakan dashboard pada sistem informasi akuntansi pembelian dan penjualan barang telah dilakukan penerapan kepada pengguna sistem UD Apung yang akan menggunakan sistem tersebut. Hasil evaluasi sistem yang telah digunakan sistem monitoring aplikasi dengan menggunakan dashboard pada sistem informasi akuntansi pembelian dan penjualan barang layak diterapkan pada UD Apung berdasarkan hasil pengujian yang telah dilakukan oleh pengguna system.

\section{Kesimpulan}

Berdasarkan hasil uraian yang telah dipaparkan pada bab-bab sebelumnya makan dapat diambil simpulan yaitu

1. Monitoring aplikasi dengan menggunakan dashboard dilakukan dengan melihat transaksi penjualan dan pembelian barang yang terjadi ditampilkan dalam bentuk grafik sehingga pimpinan dapat mengetahui secara cepat jumlah total transaksi pembelian dan penjualan yang terjadi pada perusahaan. Serta proses input data penjualan dan pembelian tidak memerlukan pencatatan secara manual seperti yang terjadi pada prosedur yang telah berjalan, sehingga dapat mengurangi kesalahan dalam melakuka input data penjualan dan pembelian yang akan menyebabkan kerugian perusahaan.

2. Hasil pengujian fungsionalitas sistem terhadap halaman yang terdapat pada monitoring aplikasi dengan menggunakan dashboard pada sistem informasi akuntansi pembelian dan penjualan barang 
diperoleh kesimpulan bahwa hasil pengujian tersebut yang telah sesuai dengan hasil yang diharapkan telah sesuai dalam kuisioner pengujian black box testing dengan nilai $100 \%$. Hasil pengolahan data tanggapan responden sebanyak 6 responden berdasarkan 5 kriteria Model DeLone dan McLeon maka didapatkan hasil kualitas informasi (information quality), kualitas sistem (system quality), kualitas layanan (service quality), penggunaan (use), dan kepuasan pengguna (use satisfaction) dari keseluruhan kriteria Model DeLone dan McLean untuk kesuksesan sistem informasi sebesar 81,37\% dengan kriteria baik.

\section{Saran}

Berdasarkan hasil penelitian yang telah dibahas, maka beberapa hal yang disarankan adalah

1. Sistem informasi akuntansi pembelian dan penjualan barang dagang pada UD Apung dapat ditambahkan proses pengeluaran kas untuk biaya pengiriman barang kepada pelanggan, proses pengeluaran kas untuk penggajian karyawan, proses pengeluaran kas untuk biaya pengeluaran kas pada UD Apung.

2. Sistem informasi akuntansi penerimaan dan pengeluaran kas pada UD Apung dapat ditambahkan proses laporan keuangan dalam sistem informasi akuntansi.

\section{Daftar Pustaka}

DELONE, W. H. AND MCLEAN, E. R. 2003. The DeLone and McLean Model of Information Systems Success : A Ten-Year Update. 19(4), pp. 9-30.

Few, S. 2006. Information Dashboard Design. Sebastapol, CA : O' Reilly Media.

Malik, S. 2005. Enterprise Dashboard-Design and Best Practice for IT. John Wiley \& Sons,Inc.

ROMNEY, M. B., STEINBART, P. J. 2014. Accounting Information Systems (Edisi 13), Prentice Hall.

SUHAIDIR, W., SENSUSE, I. 2010. Perancangan Digital Dashboard System Untuk Menyajikan Sensitivity Analysis Kinerja Keuangan Perusahaan Studi Kasus: PT XYZ. Journal of Information Systems, 6(2), pp. 94-107.

SULISTIANI, H., SULISTIAWATI. 2018. Perancangan Dashboard Interaktif Penjualan (Studi Kasus : PT JAYA BAKERY ), 12(1), pp. 15-17. Universitas Teknokrat Indonesia.

WIDYATMINI, FARADILA, K. 2014. Analisis dan perencanaan sistem informasi akuntansi penerimaan kas dengan model rea. 8(Kommit), pp. 432-445. 